\title{
REVIEWS.
}

INDUSTRIAL MALADIES.

By Sir Thomas Legge, C.B.E., M.D., D.P.H.

Edited by S. A. Henry, M.A., M.D., D.P.H., D.T.M. Oxford University Press. London. Humphrey Milford. 1934.

$$
12 / 6 \text { net. }
$$

This posthumous work at once takes an important place in the literature of Industrial Medicine, and more especially in regard to the notification, compensation, and prevention of Industrial Diseases and Poisonings. Appointed in 1898 the first Medical Inspector of Factories, Legge was immediately confronted with many medical problems in the reports of Factory Inspectors and Certifying Surgeons. Not that these had been altogether neglected. Far otherwise in a number of cases, but his full powers of entry and investigation coupled with a sort of roving commission, enabled him to piece the evidence which in any one place might be fragmentary. In this way he accomplished a large amount of valuable work, mostly initiated for him by others. Like most Government Departments, the Home Office, by tradition and otherwise, "leads the Army from behind", and as the years passed Legge irked at the sluggish pace, not even of steady progress, but of a step or two forwards and one or two back. This repression led him to suggest work to others for which he and his assistants alone had the powers of inspection and protection. Ultimately it led him to make the very great sacrifice of resigning his post in 1926 on a matter of policy, when he was allowed to depart by the government of the day, almost without notice.

The bulk of his work appeared in the yearly reports of the Chief Inspector of Factories, and in special brochures from time to time. In this book he has assembled the bulk of the available statistics gathered officially in Great Britain for the past generation, and much of it is presented in tables and charts. These alone make the book valuable to all practitioners of medicine, but Legge's history of some of the maladies and of the evolution of the present practice of official industrial hygiene make it doubly so. It should become part of the required reading of the medical student in the revised curriculum.

Space only permits of allusion to two outstanding bits of Legge's work. Early in his career he investigated outbreaks of Tetanus among workers in jute, and he made the pregnant suggestion that the germs might be in the Indian soil adherent to the jute as imported and this proved to be so. Then in regard to Anthrax, he studied the production of Sclavo's serum on the spot, and his advocacy led to its use with gradual supplanting of operative procedures. In these two instances he was not baulked of his reward by having to accommodate his recommendations to the jig-saw puzzle of conflicting interests.

\section{THE ANEMIAS.}

\section{By Janet M. Vaughan. Oxford Medical Publications. 1934. Price 12/6.}

Dr. Vaughan has performed a distinct service to medicine in bringing together all the recent work on normal erythropoiesis and on the diseases with which impaired blood formation is associated. In this work she has received the expert help of the pathologist (Prof. H. M. Turnbull) a collaboration which has enhanced considerably the value of the volume.

We have no doubt that the author herself is appalled at the complex classification which must perforce be suggested at the present time, but we have also no doubt that with the passage of time this will be simplified. At any rate it is only by placing such a detailed review of the subject as Dr. Vaughan's in the hands of all interested workers that this salutary eventuality will come to pass.

It is impossible in a review to discuss the matter of the treatise in detail; it is sufficient to say that it is a perfect mine of documentary evidence, culled not only from the author's own rich experience but also from that of other workers recorded in the literature, on every phase of normal and pathological hæmatopoiesis. Indeed, therein lies its virtue, so that it is a perfect vade mecum on anæmia. 